\title{
Latvian Writers' Strategies of Resistance during De-Stalinisation: The Case of Gunārs Priede
}

\begin{abstract}
Latvian Writers' Strategies of Resistance during De-Stalinisation: The Case of Gunārs Priede. This paper traces developments in the Soviet Latvian literary scene between the late 1950s and early 1970s. The first part examines aspects of social organisation as demonstrated by the daily routines of so-called creative unions characteristic for the overall pattern of the way in which social mechanisms worked under Soviet rule, even if there were constant attempts to overcome the limits set to expression by the communist system. The second part provides a case study of the biography and creative work of Latvian playwright Gunārs Priede (1928-2000), a leading representative of the young generation of authors of that period. The paper not only points towards the parallels in social and aesthetic developments at the Soviet periphery, but also discusses the clearly observable illogicality and unpredictability of the decisions made by Soviet officials which mirror the absurdity of the social foundations of communist rule.
\end{abstract}

Keywords: de-Stalinisation, Soviet periphery, Latvian Soviet Writers' Union, strategies of resistance, Gunārs Priede

\section{Introduction}

This paper traces developments on the literary scene of Soviet Latvia between the late 1950s and early 1970s. It is roughly divided into two parts: in the first part, the aspects of social organisation as demonstrated by the daily routines of so-called cre-

* Address: Institute of Literature, Folklore and Art, Mūkusalasiela 3, LV-1423, Riga, Latvia. E-mail: benedikts.kalnacs@lulfmi.lv. 
ative unions (especially the Latvian Soviet Writers' Union) are examined, while the second part provides a case study of the biography and creative work of Latvian playwright Gunārs Priede (1928-2000), a leading representative of the young generation of authors of that period. The paper points toward the parallels in social and aesthetic developments at the Soviet periphery, as well as discusses the long-lasting impact that the obviously illogical and unpredictable decisions made by Soviet officials had on creative personalities. The existing links between party officials and writers are also demonstrated by Priede's case. For considerably long periods of time Priede had been serving as one of the secretaries of the Latvian Soviet Writers' Union and was also working at the Union of Cinematographers' of Soviet Latvia. At the same time he was brutally exposed to censorship and the suspension of his literary works. His social prominence neither protected him from harsh ideological criticism, nor had a positive impact on the aesthetic evaluation of his works.

On 5 January 1972, after seeing two of his plays performed on the same day, written in 1958 and 1960 respectively, Priede wrote in his diary: "Both productions, so crucially different, are based on two very different plays. What was broken inside of me exactly then, between my 29th and 31st year?"1. This question might not only relate to the inner development of the author, but also point toward the crash of the rising tide of Latvian national communist activities in the late 1950s. This, the first of Priede's crises, was followed by another towards the late 1960s, when his play Smaržo sēnes (The Scent of Mushrooms, 1967) was not accepted for staging and his other works were suspended for several years to come. During this period Priede felt deeply alienated from theatre circles in Latvia, as he wrote repeatedly in his diary. This is also demonstrated in the memories of his theatre colleagues, for example stage director Ādolfs Šapiro ${ }^{2}$. More than that, his confidence was deeply shattered, and, even while continuing to write plays, Priede was not convinced that he would ever be given an opportunity to produce them. It is interesting to trace Priede's inner development. We can take the debut of his first play to reach the stage, Jaunāka brāla vasara (Younger Brother's Summer, 1955), which brought him not only recognition for being a new and bright dramatic talent, as a starting point. The plays he wrote only a few years later, during the 1960s, depicted a much bleaker view of Soviet society. A few years after that, in the late 1960s and early 1970s, his works were banned from the stage. During that period Priede's diaries and the memoirs of his contemporaries provide fodder for psychological analysis of the man and insight into the frame of mind of the nation. Priede's development mirrors the unpredictable twists and turns of Soviet ideology, including the partly conscious and partly unconscious distortion of all potentially positive signals from the imperial centre to the periphery. Obfuscation often made things in the periphery even worse. Latvian writers undertook different strategies to advance their literary careers during the 1950s and 1960s.

${ }^{1}$ G. Priede, Dzìve un darbi 1969-1976, Rīga 2015, p. 205. "Bet abas izrādes, tik krasi atškịīịas, balstās uz divām atškịirīgām lugām. Kas manī tā pārlūza tieši toreiz, starp 29. un 31. gadu?”.

2 Ā. Šapiro, Starp-brìdis, Rīga 1991, pp. 66-68. 
Ieva Struka, a theatre researcher who has compiled a new edition of Priede's works, which also contain his extensive diaries and letters, aptly compares his literary activities in the 1960s to the courageous effort of Icarus making the best of his flight while his self-made wax wings were melted by the rays of the sun as he came too close to it. In similar fashion, the hopes of the young generation of Latvian writers were at times high-flying, but soon were confronted with the pressures of Soviet reality.

\section{Activities and social contexts of the Latvian Soviet Writers' Union}

The period between the late 1950s and early 1970s in Soviet Latvia has two points of reference. Firstly, it is characterised by the process of de-Stalinisation, initiated by the twentieth congress of the Communist Party in 1956, especially by the Secret Speech of Nikita Khrushchev who by then had established himself as the new party leader. Secondly, it was also influenced by the climate of the Cold War. The relevant responses to these factors were rather varied when we think either in terms of allSoviet scale, or in the contexts of specific peripheries, such as, for example, Soviet Latvia.

In the context of post-1956 and the Secret Speech, Polly Jones comments that "these official statements made criticism of Stalin and exploration of terror - the two most important themes explored during de-Stalinisation - a legitimate focus of public discussion and an obligatory theme for Soviet literature and historiography. [...] The exposure of the cult of personality, substantively initiated by the Secret Speech, was orchestrated within this context of revived optimism about public criticism and self-criticism as a tool of reform, though it also tested the limits of this glasnost"3. The public response to the possibility to transform whispered opinions into clear speech was widespread and positive. The people welcomed the freedom to criticise, and this sentiment also entered literary texts. For example, in Latvia one of the leading poets, Ojārs Vācietis (1933-1983), wrote a novelette, Tās dienas acìm (Through the Eyes of Those Days, 1959) where he touched upon the issue of deportation, tackling the fate of many Latvian people who were forcefully dispatched to remote areas of the Soviet Union, especially in the 1940s. Vācietis's text is written in the intimate form of a diary, which includes a letter from a father to his son (the protagonist of the novelette). Not only a personal and intimate tone is preserved, but also different and mutually complementary perspectives are provided. Alongside the relatively freethinking narrative, the subjectivity of the novelette was especially striking in the context in which it was published.

However, if one compares the positions of political leaders in the geographical and ideological centre and in the periphery (in this last case Soviet Latvia), one can

3 P. Jones, Myth, Memory, Trauma: Rethinking the Stalinist Past in the Soviet Union, 1953-1970, New Haven and London 2013, p. 8. 
find it striking that local communists took a more conservative stance towards the re-evaluation of the past. Already during the height of the Stalinist era of the late 1940s, every criticism expressed in the central press was mimicked, often with an even stronger condemnation of any expression of free thought, by the local authorities. Following the Secret Speech, there were initially indeed signs of a "thaw" in Latvian cultural and political life. The national communists promoted their ideas in the second half of the 1950s. However, political leadership was internally divided. There was a deep rift between the democratic and conservative wings. The conservatives were constantly cautioning authors and artists not to go too far in their social criticism, as that would provide an inappropriate depiction of Soviet reality. In fact, criticism of any kind generally did not move beyond descriptions of personal faults of individual members of society instead of an attempt to diagnose the whole of the social order.

The situation worsened significantly after the national communists lost their positions with the purges in the party leadership in June, 1959. According to William D. Prigge, "[ $t$ ]he national communists' vision of the future included making the Party popular with the local population, harnessing that popularity to recruit those sympathetic to their faction, and utilising their numbers to shape the debate in the context of Party democracy. Additionally, they sought greater local independence and national rights within the confines of Soviet rule"4. However, even this moderate programme, which included proposals to strengthen the use of the Latvian language in everyday life and in the school system, was met with strong opposition within the party. The conservative leadership lived in fear that the rising wave of self-actualisation would threaten the status quo and put them in danger. In the course of events the representatives of the national communist faction were sidelined, and the repressive order with corresponding measures re-established. Preventive actions were taken in order to lessen the self-confidence of the local population. Writers who were considered to threaten the political system for whatever reasons were arrested and deported. One of the most scandalous cases was the arrest of poet and translator Knuts Skujenieks (b. 1936) in 1962, who was subsequently sentenced to several years in the political prisoners' camp in Mordovia 5 .

The international context must also be taken into account in the discussion of the political development in Soviet Latvia during the 1950s and 1960s. In their encyclopaedia entry on the Cold War era, Melvin E. Page and Peggy M. Sonnenburg distinguish between four distinct chronological phases: (i) First Cold War (19461953), (ii) Oscillatory Antagonism (1953-1969), (iii) Détente (1969-1979), and (iv) Second Cold War (1979-1989) 6 . If the period of Détente was also marked by an

${ }^{4}$ W. D. Prigge, "Power, Popular Opinion, and the Latvian National Communists", Journal of Baltic Studies 2014, no. 45/3, p. 306.

5 M. Čaklais, Laiks iegravē sejas, Rīga 2000, p. 43.

6 Colonialism: An International, Social, Cultural, and Political Encyclopedia, ed. E. M. Page, P. M. Sonnenburg, vol. 1, Santa Barbara, Denver and Oxford 2003, p. 127. 
attempt to "separate or disentangle the different international tensions which are in the periods of Cold War bound together by the conflict of East and West", according to political analyst Fred Halliday ${ }^{7}$, the previous decade and a half was indeed marked by confrontations on an international scale. In Latvian contexts, the situation was made even more sensitive by the existence of the exile community, which was rather vocal in expressing its political ambition to fostering an uncompromising attitude toward the Soviet occupation of the Baltic countries, trying to attract the attention of the governments in the West, especially in the USA, to this issue ${ }^{8}$. The question of how to formulate the position of the communist state against national communities in exile was constantly the focus of debates in the Soviet Union. Alongside the policy of flat denial, there were attempts to establish special organisations (in Latvia - the Committee for Cultural Relations with Compatriots Abroad), which would promote contacts between writers in Soviet Latvia and their compatriots in the West through organising strictly controlled meetings, part of the tactical game of the communist party ${ }^{9}$. After the defeat of the national communists, however, the conservative leaders were keen to avoid any shadow that relationships with dissidents in the West might cast over them.

In this context it is relevant to ask how authors positioned themselves in the political landscape, and what role was played by the only officially admitted professional organisation, the Latvian Soviet Writers' Union (established in 1940 following the Soviet invasion). The situation was more complex than it might be perceived at first glance. The authors who started their literary careers during "the thaw" were much better prepared and ready to express their own opinion, as the case of Ojārs Vācietis's novelette, an innovative and daring literary attempt ${ }^{10}$, already demonstrated. On the other hand, in this same text Vàcietis clearly preserved the politically correct juxtaposition of "us" and "them" while representing the presumable enemies of the Soviet system. This double perspective can be observed in the often contradictory stance writers took in their literary texts and real life, even if in this case the double perspective is an expression of naiveté of the young author who subsequently became much more critical of social reality. Zigmunds Skujiņš (b. 1926), also from the above-mentioned generation of authors, later wrote that most of his literary colleagues were also involved in Soviet authoritarian structures as party committee members, or at least they participated in the meetings of the Latvian Soviet Writers' Union, often enough occupying important positions there as well ${ }^{11}$.

7 F. Halliday, The Making of the Second Cold War, London 1993, pp. 10-11.

8 E. Annus, "The Problem of Soviet Colonialism in the Baltics", Journal of Baltic Studies 2012, no. 43/1, pp. 21-23.

9 E. Eglāja-Kristsone, Dzelzsgriezēji: Latvijas un Rietumu trimdas kontakti, Rīga 2013, p. 331.

10 I. Kalniņa, "Ojāra Vācieša garstāsts ‘Tās dienas acīm’ un Ilzes Indrānes romāns 'Lazdu laipa”, [in:] Ojārs Vācietis un viņa laiks, ed. A. Cimdiṇa, Rīga 2013, pp. 133-134.

11 Z. Skujiňš, Raksti, vol. 1, Rìga 2005, pp. 270-271. 
The Latvian Soviet Writers' Union consisted of two parallel and mutually interdependent structures - the administrative board and the party group, which did not necessarily work in unison. Membership of the Union was generally considered sine qua non for every author who wanted his works to be printed by the state publishing houses, which also meant that it comprised people with rather different opinions on important issues. All literature also had to comply with the rules of the game presided over by the so-called method of socialist realism which was omnipresent, even if a successful theoretical framework was never provided. As Estonian scholar Jaan Undusk aptly stated, "[n]either the definition of socialist realism nor its artistic achievements have made history - history was made through its political practices" ${ }^{\prime 2}$. The adaptation of certain realities of the communist state in order to secure at least a certain degree of freedom was at the core of the paradoxical mechanisms of everyday life under Soviet rule. In his study of the history of Baltic singing cultures, Guntis Šmidchens observes that song festivals gained their popularity from a carnivalesque dialogue with the dominant Soviet ideology. On the one hand, "[r] egardless of the beliefs within people's minds, symbolic public displays of submission maintained Soviet power structures, confirming the Communist Party's leading role in the Soviet Union"13. Still, gatherings of nationally unified crowds during song festivals (and theatre performances) demonstrated a tangible national solidarity during the period when informal public meetings were generally suppressed.

In the generally conservative political climate, it is important to stress the decisions made by the Writers' Union contained seeds of resistance. Compared to the usual predictability of all elections carried out during the Soviet period, it is especially striking that in the December 1965 elections to the board of the Writers' Union, several representatives of the conservative wing who were promoted by the communist party did not gain a sufficient number of votes from their colleagues and were replaced by writers from the younger generation. Internally, this was considered a coup détat and provoked retaliation from the party cell. Māris Čaklais (1940-2003) remembered how conspiracy was at work while preparing the elections, as most of the informal gatherings prior to the event were held in the apartments of the poet Vizma Belševica (1931-2005) and dramatist Gunārs Priede ${ }^{14}$. In 1972, Priede himself was elected the first secretary of the board. This took place at the time when his plays were banned from the stage.

On a number of occasions, the activities of the Latvian Soviet Writers' Union were characterised by non-compliance. Precisely this kind of opposition mounted into open protest in the late 1980s in the atmosphere of the generally changing pol-

12 J. Undusk, “The Fading Reality of Socialist Realism: Aesthetics as a Means of Realpolitik”, [in:] Back to Baltic Memory: Lost and Found in Literature, 1940-1968, ed. E. Eglāja-Kristsone, B. Kalnačs, Riga 2008, p. 17.

13 G. Šmidchens, The Power of Song: Non-violent National Culture in the Baltic Singing Revolution, Seattle, London and Copenhagen 2014, p. 153.

14 M. Čaklais, op. cit., p. 44. 
itical climate. The Writers' Union was the main force behind the forum of all creative unions when Soviet occupation and political and national oppression were raised publicly in Latvia for the first time in June 1988. This was an event of revolutionary importance. The events that followed rather quickly sidelined the party politicians, and the wave of resistance initiated by the intelligentsia turned into a mass movement that resulted in the declaration of independence of Latvia on May 4, 1990, and the de jure recognition of the re-established state in the autumn of 1991.

\section{Gunārs Priede and resistance models in Soviet Latvian drama}

The winds of novelty that set Soviet Latvian drama in motion in the 1950s were initiated by Gunārs Priede's first plays. In the following section we discuss the main patterns characteristic of these innovations as well as the causes of setbacks, but it is important to trace Priede's biography firstly in order to assess the contexts in which his creative work evolved.

Priede's career is an interesting example of how different and sometimes contradictory individual, educational, and social impulses merge and compete in one personality, to determine the creative output of a (Soviet) Latvian author. Priede was born in a rural part of Kurzeme, the western region of independent Latvia. As a small boy he went to primary school in the nearby town of Ventspils. Then, during the Second World War, he experienced the changing educational system as different political powers tried to promote their ideologies, and later faced the onset of socialist ideology after he entered university in Riga, studying architecture. His choice of subject, as well as his somewhat later appointment to the Institute of Architecture of the Soviet Latvian Academy of Sciences, placed him at the centre of conflicting opinions as to what should be the fate of the architectural heritage in the country in general, and in the old town of Riga in particular. Orthodox communists considered the old town to be the most prominent testament to the centuries-old presence of the arch-enemy of the Soviet people, the Germans. In his position as scientific secretary of the Institute, it became possible for Priede to intervene in the decision-making process on many occasions; he showed deep interest in preserving this heritage. $\mathrm{He}$ soon moved to a technical college where he taught for many years; and later on occupied important posts at the Cinematographers' Union (1965-1968), as well as the Writers' Union (1972-1984), including the top position as first secretary.

Despite all these official tasks, Priede often longed in vain to express himself openly as an author. This feeling was especially acute due to the fact that, from the beginning of his literary efforts, his works were rejected for ideological reasons, and he had to find ways to bypass censorship. The examination of these processes not only reveals the experience of one young author, but also documents the general climate created by Soviet power in the Baltic littoral, where one of the set tasks was 
"to uproot all reminiscences of 'bourgeois' cultural memory"15. Priede's works and their interpretation display the most characteristic models of resistance in Soviet Latvian drama, which, up to the early 1970s, demonstrate the return of realism in the portrayal of everyday life, reveal a surreptitious focus on hidden and forbidden social and political issues, and display vague traces of the theatre of the absurd.

The early success of Priede's plays from the 1950s can be explained by rather simple factors. It was the first time in Soviet Latvian drama that young people were portrayed on stage in a true to life milieu and recognisable everyday situations. Thanks to their vitality and conversational intimacy the productions staged at the Daile Theatre in Riga by the young director Pèteris Pètersons attracted wide audiences. Theatre researcher Ieva Zole remarks that Priede and Pētersons were indeed confederates in the sense of breaking the traditional rules of the portrayal of Soviet $\mathrm{life}^{16}$. Drawing on his experience as a teacher at the school of civil engineers, Priede managed to provide subtle insight into the feelings of the young protagonists of his plays, which made these characters, as well as the actors who embodied them on stage, immensely popular. Theatre critic Lilija Dzene confirms that the productions of Priede's plays created the sense of belonging to one generation which had a shared experience of war and post-war years ${ }^{17}$. Mutual understanding was created at the level of familiar daily life as opposed to official Soviet pedagogical narratives, thus providing an alternative to them.

The situation changed to a considerable extent following Priede's crisis of personality in the late 1950s that was mentioned earlier. There were no direct signs of the author's disillusionment and his plays continued to be frequently staged throughout the first half of the 1960s. The tone of his works, however, changed considerably as more psychological and social tensions were displayed through the conflicts he had chosen to portray. Signs of Priede's new creative handwriting first appear in the drama Vikas pirmā balle (Vika's First Dance, 1961). The play sharply criticised both the cynicism and impunity that had penetrated into the souls of a number of the younger generation representatives who falsely assumed that their existence would be secured and supported by their influential parents at the expense of their peers. In this play, and in the works that followed, Priede went beyond psychological character portrayals, at least indirectly, and pointed towards the corrupt roots of socialist society. For the first time in Soviet Latvian drama his plays Miks un Dzilna (Miks and Dzilna, 1962) and Tava labā slava (Your Good Name, 1964) touched upon topical issues of de-Stalinisation, memories of the terror against communist party members of the 1930s, as well as the deportations of innocent people from Latvia after the Second World War. However, regardless of the formally proclaimed party line towards the re-evaluation of the past, these topics were still considered undesirable by the communist authorities in Latvia. Therefore, these plays appeared on stage

15 J. Undusk, op. cit., p. 21.

16 I. Zole, Pēteris Pētersons, Rīga 2000, p. 137.

17 L. Dzene, Aktieris pret savu gribu, Rīga 1987, p. 47. 
with passages deleted by the censors. At times this made the message of the writer incomprehensible. Priede repeatedly refers in his diaries to the dreadful feeling he experienced when his plays were performed in a distorted shape ${ }^{18}$. In his diaries he also openly and critically referred to the processes in the Latvian communist party, which he saw as the restoration of Stalinism ${ }^{19}$.

Even apart from censorship interventions, in his new plays Priede gradually stopped depicting the intimate communication among characters he always tried to pay attention to. For him, intimacy was a sign of the verity of the relationships. With this in mind, Priede tried an experiment that was extremely unusual in Latvian theatre at the time. Together with three actors, he himself started the rehearsals of his play Trīspadsmità (The Thirteenth, 1965) in private apartments. The play eventually appeared on stage at the Youth (Jaunatnes) Theatre in Riga, although the final cast differed from the one the playwright initially envisaged. In this play, Priede explicitly attacked the suppressive mechanisms of censorship, confronting a young poet who writes song lyrics appealing to contemporary audiences, and the member of an evaluation committee who strictly opposes the presumable immorality of the young author's texts. In a somewhat later film script Četri balti krekli (Four White Shirts, 1967), based on the plot of this play, his social criticism is even more strongly articulated, since the script presents the absurd discussion of the committee leading to a decision to ban the songs. A film was based on that script, but it was not shown publicly until twenty years later. Latvian scholar Inga Pērkone remarks that the censors were especially keen to detect even the smallest signs of criticism of the social order in Soviet films; since this genre was of special appeal to broader audiences, criticism was intolerable ${ }^{20}$.

These events did not have a direct impact on Priede's writing until the banning of his drama Smaržo sēnes (The Scent of Mushrooms, 1967). This is one of the rare examples in the literary life of Soviet Latvia when a play was prevented from being staged for more than twenty years. The plot of the play tackles the corruption and immorality at the core of the communist leadership, recognisably portraying active party leaders. Priede was well aware that this text hardly had a chance of being performed under the Soviet leadership at that time. It eventually premiered in the autumn of $1988^{21}$. The ban followed several rounds of closed discussions ${ }^{22}$, with the members of drama section of the Writers' Union speaking out in support of Priede, while party officials strongly condemned the play. The final verdict was that of "artistic failure", the least dangerous option in the given circumstances. In fact, this partial reconciliation was reached only due to the support of Priede's colleagues in the discussion process. Without their support, the play might have been judged

18 G. Priede, Dzìve un darbi 1959-1968, Rīga 2014, p. 687.

19 Ibid., p. 526.

20 I. Pērkone, Inscenējumu realitāte: Latvijas aktierkino vēsture, Rīga 2011, pp. 100-105.

21 G. Priede, Dzìve un darbi 1959-1968, p. 721.

22 Ibid., pp. 871-883. 
to be anti-Soviet propaganda, which would have meant sharp political repressions against the author.

In the context of Soviet periphery, Priede's work proved to be one of the most radical challenges to the social order. As suggested earlier, the criticism rhetoric was more outspoken in the imperial centre. However, literary texts created by Soviet authors often did not go beyond the politically acceptable limits. As literary scholar Katerina Clark points out, despite the seeming radicalism of some texts, "[a] closer look at the actual substance of the changes reflected in fiction under Khrushchev reveals that they were often not as radical as the rhetoric suggests"23. Priede's play appeared to be a different matter.

The author continued to write plays during the late 1960s and early 1970s even though they were prevented from the stage for several years. The signs of the devastation he felt are visible in his diaries. On the occasion of the premiere of Priede's play Ugunskurs lejā pie stacijas (Fire down by the Station) in 1972, Pēteris Pētersons, who had staged most of the writer's earlier works, expressed the hope that this production would eventually bring joy in contrast to the events of the preceding months that included the seemingly endless postponing of the play's authorisation for the stage ${ }^{24}$. A theatre of the absurd was taking place behind every decision about what should be officially accessible. This only intensified the feeling of absurdity people had about daily life in general, a feeling partly captured in Priede's plays from the early 1970s, as well as in the productions of those plays.

\section{Conclusion}

It is difficult to speak about the presence of the theatre of the absurd in Soviet Latvia in the full aesthetic sense of the term but paradoxically enough the perception of life during this era might be compared to the mechanisms characteristic for this form of art. Martin Esslin comments that one of the tasks of the theatre of the absurd was to surprise the spectator in order to focus on the live experience of the theatrical event:

The spectators, not knowing what their author is driving at, cannot be in suspense as to how or whether an expected objective is going to be reached. They are not, therefore, so much in suspense as to what is going to happen next (although the most unexpected and unpredictable things do happen) as they are in suspense about what the next event to take place will add to their understanding of what is happening. The action supplies an increasing number of contradictory and bewildering clues on a number of different levels, but the final question is never fully answered ${ }^{25}$.

In the context of Soviet Latvia, it might be argued that it was life itself that toyed with the people, who agonisingly tried to work out what exactly the rules of the game

${ }^{23}$ K. Clark, The Soviet Novel: History as Ritual, Bloomington and Indianapolis 2000, p. 211.

24 I. Zole, op. cit., p. 43.

${ }^{25}$ M. Esslin, "The Theatre of the Absurd", The Tulane Drama Review 1960, no. 4/4, p. 5. 
might be and where the absurd communist rhetoric would further lead. Of course, people also tried to adapt to these circumstances. A characteristic example of the response to the given conditions is provided by the stage director Ādolfs Šapiro. When asked to comment on the incomprehensibility of his prepared stage version of Priede's Fire down by the Station, Šapiro formally complained, writing answers to the party enquiry. However, following the sequence of absurdly formulated inquiries step by step, and providing similarly absurd even if formally affirmative answers, the director was openly mimicking models of Soviet behaviour ${ }^{26}$. The diary entries Priede wrote during the period he waited for a decision to be made about whether or not his plays would be allowed for public display reveal that all of the people involved were consciously kept in total ignorance in regard to what final decision might be expected from the party officials ${ }^{27}$.

Martin Esslin in his analysis has argued that the "spectators of the Theatre of the Absurd are thus confronted with a grotesquely heightened picture of their own world: a world without faith, meaning and genuine freedom of will"28. Soviet reality provided a very similar picture. However, this does not mean that no attempts were made to change the status quo. Quite the contrary, the writing strategies of Latvian authors during this period often reveal conscious resistance to communist rule, despite its seeming omnipresence, as well as the incomprehensibility of the logic behind the unpredictable decisions undertaken by the authorities.

26 Ā. Šapiro, op. cit., p. 68.

27 G. Priede, Dzìve un darbi 1969-1976, pp. 353, 368, 371.

${ }^{28}$ M. Esslin, op. cit., p. 14. 